\title{
Hubungan Status Kesehatan Periodontal dengan Kebiasaan Menyirih pada Mahasiswa Etnis Papua di Manado
}

\author{
${ }^{1}$ Welmince Oktofina Fatlolona, ${ }^{2}$ Karel Pandelaki , ${ }^{3}$ Christy Mintjelungan \\ ${ }^{1}$ Mahasiswa Program Studi Kedokteran Gigi Fakultas Kedokteran \\ ${ }^{2}$ Fakultas Kedokteran \\ ${ }^{3}$ Program Studi Kedokteran Gigi Fakultas Kedokteran Universitas Sam Ratulangi
}

\begin{abstract}
ABSTRAK
Penyakit periodontal memiliki prevalensi cukup tinggi di masyarakat.. Salah satu faktor penyebab masalah kesehatan gigi dan mulut ialah faktor perilaku masyarakat yang dijadikan suatu budaya atau kebiasaan. Menyirih merupakan kebiasaan yang masih dilakukan oleh masyarakat hingga saat ini termasuk etnis Papua yang tinggal di Manado. Penelitian ini bertujuan untuk mengetahui hubungan status kesehatan periodontal dengan kebiasaan menyirih pada mahasiswa etnis Papua di Manado. Penelitian ini bersifat deskriptif analitik dengan pendekatan cross-sectional study yang dilakukan pada mahasiswa etnis Papua di Manado, dengan sampel sebanyak 42 orang. Metode pengambilan sampel menggunakan teknik purposive sampling. Pengumpulan data menggunakan kuesioner dan pemeriksaan menggunakan CPITN. Hasil penelitian ini menunjukan bahwa status kesehatan periodontal mahasiswa etnis Papua di Manado yang memilki kebiasaan menyirih termasuk buruk sebanyak 32 orang $(76,2 \%)$ dan sangat buruk sebanyak 10 orang $(23,8 \%)$. Terdapat hubungan antara frekueni menyirih dalam sehari dengan status kesehatan periodontal. Penelitian ini menunjukkan masih perlunya ditingkatkan promosi kesehatan akan dampak negatif dari kebiasaan menyirih secara terus menerus untuk merubah perilaku masyarakat etnis Papua yang masih mempertahankan kebiasaan menyirih.
\end{abstract}

Kata kunci: kebiasaan menyirih, status kesehatan periodontal, etnis Papua

\section{ABSTRACT}

Periodontal disease has a high prevalence in the community. One of the causes of oral health problems are the behavioral factors that made a culture or customs. Chewing betel is a habit that is still practiced by the community, including ethnic Papuans living in Manado. This study aims to determine the relationship of periodontal health status with the chewing betel habits of ethnic Papuan students in Manado. This is a descriptive analytic study with a cross-sectional study conducted in the ethnic Papuan students in Manado with number of samples 42 people. Method of sampling using purposive sampling. Data collection using list of questionnaires and also direct examination inspection techniques using CPITN. These results indicate that the periodontal health status of ethnic Papuan students in Manado who have the habit of chewing betel include bad as many as 32 people $(76.2 \%)$ and very bad as many as 10 people $(23.8 \%)$. There is a relationship between chewing betel frequency in a day with periodontal health status. From these results, it is expected for health clinicians to conduct health promotion of the negative impact of continuous chewing betel habit to change the behavior of ethnic Papuans student who still maintain the chewing betel habits.

Keywords : chewing betel habits, periodontal health status, ethnic Papuans

Korespondensi: Welmince Oktofina Fatlolona, Program Studi Kedokteran Gigi Fakultas Kedokteran Universitas Sam Ratulangi. E-mail: welmincfat@yahoo.com 


\section{PENDAHULUAN}

Kesehatan mulut penting bagi kesehatan dan kesejahteraan tubuh secara umum dan sangat memengaruhi kualitas kehidupan termasuk fungsi bicara, pengunyahan dan rasa percaya diri. Ganguan kesehatan mulut akan berdampak pada kinerja seseorang. Masalah tingginya angka penyakit gigi dan mulut saat ini sangat dipengaruhi oleh beberapa faktor antara lain faktor perilaku masyarakat yang dijadikan suatu budaya atau kebiasaan salah satunya adalah kebiasaan mengunyah sirih. ${ }^{1}$

Di kawasan Asia Tenggara, tradisi mengunyah sirih sudah dimulai sejak 3.000 tahun yang lalu. Tradisi mengunyah sirih tidak dapat dipastikan dari mana asalnya. Tidak sedikit orang yang mengatakan bahwa tradisi mengunyah sirih berasal dari India. Pendapat ini lebih didasarkan pada cerita-cerita sastra dan sejarah lisan. Bedasarkan catatan perjalanan Marcopolo, yang dikenal sebagai penjelajah pada abad ke-13 mencatat bahwa mayarakat di kepulauan nusantara banyak yang makan sirih. ${ }^{2}$

Di Indonesia kebiasaan mengunyah sirih merupakan kebiasaan yang dilakukan oleh berbagai suku di Indonesia diantaranya terdapat dalam jumlah yang cukup banyak di pedesaan. Kebiasaan ini merupakan kebiasaan yang dilakukan turun temurun pada sebagian besar penduduk di pedesaan yang mulanya berkaitan erat dengan adat kebisaan setempat. Adat kebiasaan ini dilakukan pada saat upacara kedaerahan atau pada acara yang bersifat ritual keagamaan.

Kebiasaan mengunyah sirih atau pada kelompok etnis Papua disebut sebagai menginang dikenal oleh seluruh etnis Papua. Kebiasaan mengunyah sirih tidak berbeda dengan praktek kenikmatan lain, seperti tambkau, teh dan kopi sehingga orang yang mengunyah sirih sukar untuk menghilangkan kebiasaan tersebut, mengunyah sirih mempunyai efek positif karena bahan yang digunakan mengandung antiseptik yang dapat memperkuat gigi. Disamping itu sirih yang dikunyah dapat mengurangi bahaya karies gigi dan menjaga kesehatan mulut. Hal ini terjadi karena daun sirih mempunyai aktifitas antioksidan. Kebiasaan ini sudah lama dilakukan oleh wanita maupun pria baik tua maupun muda. Kebiasaan ini kemudian berlanjut menjadi kesenangan yang sulit untuk dilepaskan. Kebiasaan mengunyah sirih pada masyarakat Papua suda menjadi budaya yang tidak memperhatikan umur, ras, pangkat dan golongan. Hal tersebut sudah menjadi kebiasaan yang mengakar kuat dalam masyarakat sehingga diharapkan dapat mempererat tali persaudaraan dalam keseharian kehidupan masyarakat Papua. setiap suku pada etnis paua memiliki koposisi mengunyah sirih yang cukup beragam yaitu piang (areca catechu L), sirih (piper Betle L), gambir (Uncaria Gambir Roxburgh), kapur dan tembakau. Bagian tanaman sirih yang paling sering dimnfaatkan yaitu buah, akar, batang dan daunnya. Bagian pinang yang dimanfaatkan yaitu buah muda ${ }^{4.5 .6}$

Dalam tulisan ini, penulis ingin menjelaskan mengenai gambaran kesehatan jaringan periodontal yang berhubungan dengan kebiasaan mengunyah sirih. Karena hingga sekarang ini sebagian besar masyarakat belum bisa menyadari bahwa kebiasaan mengunyah dapat memengarui kesehatan rongga mulut, salah satuya dapat merusak jaringan periodontal. Berdasarkan latar belakang di atas maka penulis merasa tertarik untuk melakukan penelitian tentang hubungan status kesehatan periodontal dengan kebiasaan menyirih pada mahasiswa etnis Papua di Manado.

\section{BAHAN DAN METODE}

Jenis penelitian yang digunakan adalah deskriptif analitik dengan pendekatan cross- sectional study. Pemilihan sampel menggunakan teknik purposive sampling, dan diperoleh 42 
responden dari mahasiswa etnis Papua di Manado yang memiliki kebiasaan menyirih.

Pengumpulan data diperoleh melalui studi lapangan. Responden diminta mengisi lembar informed consent dan menjawab daftar pertanyaan mengenai lama menyirih, frekuensi menyirih, dan komposisi ramuan menyirih yang dapat dilihat pada tabel 1 .

Langkah selanjutnya ialah pemeriksaan klinis responden. Responden diminta untuk membuka mulutnya untuk dilihat status kesehatan jaringan periodontal sesuia indeks periodontal berdasarkan prinsip CPITN. Hasil pemeriksan dicatat pada lembar pemeriksaan. Data kuesioner diolah dengan menggunakan program statistical package for the social sciences (SPSS).

Status Kesehatan periodontal adalah suatu keadaan pada jaringan periodontal yang memperlihatkan kondisi sehat, perdarahan pada gusi, terdapat karang gigi, poket dangkal, poket dalam, dan diukur berdasarkan skala ordinal. Baik, jika kondisi periodontal dalam keadaan sehat, yaitu tidak ada perdarahan, tidak ada karang gigi dan tidak ada poket. Buruk, jika kondisisi periodontal dalam keadaan ada perdarahan dan ada karang gigi atau salah satu diantaranya. Dan sangat Buruk, jika kondisi periodontal dalam keadaan ada poket dangkal (3,5$5,5 \mathrm{~mm}$ ) dan poket dalam ( > 5,5 $\mathrm{mm}$ ).

Tabel 1. Kuesioner penelitian

\begin{tabular}{|c|c|c|}
\hline No & Pertanyaan & Jawaban \\
\hline 1. & Berapa lama anda menyirih? & $\begin{array}{ll}\text { a. } & 2-5 \text { tahun } \\
\text { b. } & 6-10 \text { tahun } \\
\text { c. } & >10 \text { tahun } \\
\end{array}$ \\
\hline 2. & $\begin{array}{l}\text { Kapan saja mengunyah sirih } \\
\text { dilakukan? }\end{array}$ & $\begin{array}{ll}\text { a. } & 7 \mathrm{kali} / \mathrm{minggu} \\
\text { b. } & 3-6 \mathrm{kali} / \mathrm{minggu} \\
\text { c. } & <3 \mathrm{kali} / \mathrm{minggu} \\
\end{array}$ \\
\hline 3. & $\begin{array}{l}\text { Berapakali dalam satu hari anda } \\
\text { menyirih? }\end{array}$ & $\begin{array}{ll}\text { a. } & <3 \mathrm{kali} \\
\text { b. } & 3-5 \mathrm{kali} \\
\text { c. } & >5 \mathrm{kali} \\
\end{array}$ \\
\hline 4. & $\begin{array}{l}\text { Berapa waktu yang dibutuhkan } \\
\text { untuk mengunyah sirih dalam } \\
\text { sekali menyirih? }\end{array}$ & $\begin{array}{ll}\text { a. } & <15 \text { menit } \\
\text { b. } & 15-30 \text { menit } \\
\text { c. } & >30 \text { menit } \\
\end{array}$ \\
\hline 5. & $\begin{array}{l}\text { Apa saja ramuan komposisi bahan } \\
\text { menyirih? }\end{array}$ & $\begin{array}{l}\text { a. Kapur, pinang, tembakau, daun sirih } \\
\text { /buah sirih, gambir } \\
\text { b. Kapur, pinang, tembakau, daun sirih } \\
\text { /buah sirih } \\
\text { c. Kapur, pinang, daun sirih /buah sirih }\end{array}$ \\
\hline
\end{tabular}




\section{HASIL PENELITIAN}

Hasil penelitian dapat dilihat pada tabel berikut:

Tabel 2. Distribusi status kesehatan periodontal.

\begin{tabular}{ccc}
\hline Status Periodontal & $\begin{array}{c}\text { Jumlah } \\
(\mathrm{n})\end{array}$ & $\begin{array}{c}\text { Persentasi } \\
(\%)\end{array}$ \\
\hline Buruk & 32 & 76,2 \\
\hline Sangat Buruk & 10 & 23,8 \\
\hline Total & 42 & 100 \\
\hline
\end{tabular}

Tabel 3. Hubugan lama kebiasaan menyirih dengan status kesehatan periodontal

\begin{tabular}{|c|c|c|c|c|c|c|c|c|}
\hline \multirow{4}{*}{$\begin{array}{c}\text { Lamanya } \\
\text { kebiasaan } \\
\text { (tahun) }\end{array}$} & \multicolumn{3}{|c|}{ Status } & Kesehatan & \multicolumn{2}{|c|}{ Periodontal } & \multirow{2}{*}{\multicolumn{2}{|c|}{ Total }} \\
\hline & & & & & & & & \\
\hline & \multicolumn{2}{|c|}{ Baik } & \multirow[b]{2}{*}{$\mathrm{n}$} & Buruk & \multicolumn{2}{|c|}{ Sangat } & & \\
\hline & $\mathrm{n}$ & $\%$ & & $\%$ & $\mathrm{n}$ & $\%$ & $\mathrm{n}$ & $\%$ \\
\hline $2-5$ & 0 & 0 & 8 & $(19 \%)$ & 2 & $(4,8 \%)$ & 10 & $(23,8 \%)$ \\
\hline $6-10$ & 0 & 0 & 13 & $(31 \%)$ & 4 & $(9,5 \%)$ & 17 & $(40,4 \%)$ \\
\hline$>10$ & 0 & 0 & 11 & $(26,2 \%)$ & 4 & $(9,5 \%)$ & 15 & $(35,7 \%)$ \\
\hline total & 0 & $(0 \%)$ & 32 & $(76,2 \%)$ & 10 & $(23,8 \%)$ & 42 & $(100 \%)$ \\
\hline
\end{tabular}

Tabel 4. Hubungan frekuensi menyirih dalam seminggu dengan status kesehatan periodontal

Frekuensi

Status Kesehatan Periodontal (per Minggu)

Total

\begin{tabular}{ccccccccc} 
& \multicolumn{2}{c}{ Baik } & \multicolumn{2}{c}{ Buruk } & Sangat & buruk & & \\
\cline { 2 - 9 } & $\mathrm{n}$ & $\%$ & $\mathrm{n}$ & $\%$ & $\mathrm{n}$ & $\%$ & $\mathrm{n}$ & $\%$ \\
\hline 7 & 0 & 0 & 7 & $(16,7 \%)$ & 5 & $(11,9 \%)$ & 12 & $(28,6 \%)$ \\
\hline $3-6$ & 0 & 0 & 7 & $(16,7 \%)$ & 2 & $(4,8 \%)$ & 9 & $(21,4 \%)$ \\
\hline$<3$ & 0 & 0 & 18 & $(42,9 \%)$ & 3 & $(7,1 \%)$ & 21 & $(50 \%)$ \\
\hline total & 0 & $(0 \%)$ & 32 & $(76,2 \%)$ & 10 & $(23,8 \%)$ & 42 & $(100 \%)$ \\
\hline
\end{tabular}


Tabel 5. Hubungan frekuensi menyirih dalam sehari dengan status kesehatan periodontal

\begin{tabular}{|c|c|c|c|c|c|c|c|c|}
\hline \multirow{3}{*}{$\begin{array}{l}\text { Frekuensi } \\
\text { (per Hari) }\end{array}$} & \multicolumn{3}{|c|}{ Status } & Kesehatan & \multicolumn{2}{|c|}{ Periodontal } & \multicolumn{2}{|r|}{ Total } \\
\hline & & & & & Sangat & buruk & & \\
\hline & $\mathrm{n}$ & $\%$ & $\mathrm{n}$ & $\%$ & $\mathrm{n}$ & $\%$ & $\mathrm{n}$ & $\%$ \\
\hline$<3$ & 0 & 0 & 21 & $(50 \%)$ & 2 & $(4,8 \%)$ & 23 & $(54,8 \%)$ \\
\hline $3-5$ & 0 & 0 & 7 & $(16,7 \%)$ & 3 & $(7,1 \%)$ & 10 & $(23,8 \%)$ \\
\hline$>5$ & 0 & 0 & 4 & $(9,5 \%)$ & 5 & $(11,9 \%)$ & 9 & $(21,4 \%)$ \\
\hline Total & 0 & $(0 \%)$ & 32 & $(76,2 \%)$ & 10 & $(23,8 \%)$ & 42 & $(100 \%)$ \\
\hline
\end{tabular}

Tabel 6. Hubungan frekuensi waktu yang dibutuhkan untuk mengunyah sirih dalam sekali menyirih dengan status kesehatan periodontal

Status Kesehatan Periodontal

Total

\begin{tabular}{|c|c|c|c|c|c|c|c|c|}
\hline \multirow{3}{*}{$\begin{array}{c}\text { Frekuensi } \\
\text { (permenit) }\end{array}$} & & & & & & & \multicolumn{2}{|r|}{ Total } \\
\hline & \multicolumn{2}{|c|}{ Baik } & \multicolumn{2}{|c|}{ Buruk } & \multirow{2}{*}{$\frac{\text { Sang }}{\mathrm{n}}$} & buruk & & \\
\hline & $\mathrm{n}$ & $\%$ & $\mathrm{n}$ & $\%$ & & $\%$ & $\mathrm{n}$ & $\%$ \\
\hline$<15$ & 0 & 0 & 19 & $(45,2 \%)$ & 6 & $(14,3 \%)$ & 25 & $(59,5 \%)$ \\
\hline $15-30$ & 0 & 0 & 9 & $(21,4 \%)$ & 3 & $(7,1 \%)$ & 12 & $(28,6 \%)$ \\
\hline$>30$ & 0 & 0 & 4 & $(9,5 \%)$ & 1 & $(2,4 \%)$ & 5 & $(11,9 \%)$ \\
\hline total & 0 & $(0 \%)$ & 32 & $(76,2 \%)$ & 10 & $(23,8 \%)$ & 42 & $(100 \%)$ \\
\hline
\end{tabular}

\section{PEMBAHASAN}

1. Status kesehatan periodontal

Dalam penelitian ini status kesehatan periodontal di kategorikan dalam 3 kelompok yaitu baik, buruk dan sangat buruk. Berdasarkan tabel 2 menunjukan bahwa keadaan status kesehatan periodontal pada mahasiswa etnis Papua yang memilki kebiasaan menyirih di Manado termasuk kategori buruk sebanyak 32 orang $(76,2 \%$.) sedangkan status kesehatan periodontal pada mahasiswa etnis Papua yang memiliki kebisaan menyirih di Manado termasuk kategori sangat buruk sebanyak 10 orang $(23,8 \%)$. Dalam penelitian ini tidak di temukan responden yang memiliki status kesehatan periodontalnya baik yang berarti seluruh responden menderita penyakit periodontal akibat menyirih. Hal yang sama terjadi pada pada penelitian Jul Asdar Putra Samura pada masyarakat suku Karo yang juga memiliki kebiasaan menyirih. 
Selain pendapat dari masyarakat yang mengatakan bahwa kebiasaan menyirih dapat memperkuat gigi, teori juga mengatakan bahwa beberapa ramuan bahan menyirih memiliki kandungan yang memberikan dampak positif terhadap kesehatan gigi dan mulut. Jika dibandingkan dengan hasil penelitian yang didapat bahwa semua responden mengalami kerusakan jaringan periodontal maka kemungkinan faktor-faktor yang mendukung terjadinya kerusakan jaringan periodontal pada para penyirih yaitu kebersihan mulut atau Oral Hygiene $(O H I-S)$ yang tidak dijaga, iritasi zat yang terus menerus, serta usia dari penyirih tersebut. ${ }^{4.8}$ Pendapat ini pun diperkuat dengan hasil penelitian yang dilakukan oleh Krista Veronica Siagian pada masyarakata Papua di Manado yang memiliki kebiasaan menyirih atau pada masyarakat Papua disebut menginang didapat, skor kalkulus pada pengunyah pinang atau penyirih cenderung tinggi, dikarenakan terbentuknya karang gigi yang disebabkan adanya stagnasi saliva dan terdapatnya kalsium pada campuran komposisi bahan yang digunakan pada saat menginang atau menyirih., ${ }^{4,7}$ berdasarkan kuesioner responden paling banyak memiliki lama menyirih 6-10 tahun sebanyak 17 orang $(40,4 \%)$.Berdasarkan uji korelasi menggunakan chi-square test, hubungan lama kebiasaan menyirih dengan status kesehatan periodontal diperoleh hasil $p=0,929 \quad(p>0,05), \quad$ sehingga dapat disimpulkan bahwa tidak ada hubungan atau pengaruh yang signifikan antara lama kebiasaan menyirih dengan status kesehatan periodontal.Berdsarkan hsil penelitian menggunakan kuesioner, .jumlah waktu yang dibutuhkan untuk mengunyah sirih dalam sekali menyirih paling banyak < 15 menit. Sebanyak 25 responden (59,5\%). Berdasarka uji korelasi menggunakan chi-square test, hubungan lama waktu yang dibutuhkan untuk mengunyah sirih dalam sekali menyirih (menit) dengan status kesehatan periodontal diperoleh hasil $p=0,975$ $(p>0,05)$ sehingga dapat disimpulkan tidak terdapat hubungan atau pengaruh yang signifikan antara frekuensi waktu yang dibutuhkan untuk mengunyah sirih dalam sekali menyirih dengan status kesehatan periodontal. Lama kebiasaan menyirih responden sangat bervariasi antara satu dengan yang lain, dikarenakan ketertarikan untuk menyirih merupakan kebiasaan yang dilakukan atas dasar keinginan pribadi dan pengetahuan masyarakat yang menganggap bahwa menyirih dapat menguatkan gigi, selain unsur kebudayaan yang mengharuskan kebiasaan ini dilakukan saat kegiatan adat istiadat atau upacara keagamaan. ${ }^{5}$

Dari hasil penelitian menggunakan kuesioner didapat kebiasaan responden menggunakan kebiasaan menyirih paling banyak kurang dari 3 kali dalam seminggu dengan jumlah responden 21 orang $(50 \%)$. Berdasarkan uji korelasi menggunakan chi-square test, hubungan frekuensi kebiasaan menyirih dalam seminggu dengan status kesehatan periodontal diperoleh hasil $p=0,205 \quad(p>0,05)$, sehingga dapat disimpulkan tidak terdapat hubungan atau pengaruh yang signifikan antara frekuensi kebiasaan menyirih dalam seminggu dengan status kesehatan periodontal.

Dari hasil penelitian menggunakan kuesioner didapat responden yang paling banyak melakukan kebiasaan menyirih kurang dari 3 kali dalam sehari dengn jumlah responden 23 orang $(54,8 \%)$. Berdasarkan uji korelasi menggunakan chi-square test, hubungan frekuensi kebiasaan menyirih dalam sehari dengan status kesehatan periodontal diperoleh hasil $p=0,017 \quad(p<0,05)$ yang artinya terdapat hubungan atau pengaruh yang signifikan antara frekuensi menyirih dalam sehari dengan status kesehatan periodontal 
Beerdsarkan hasil wawancara dengan responden, tidak seperti halnya di Papua untuk memperoleh komposisi ramuan bahan menyirih sangat mudah dan dengan harga yang terjangkau oleh masyarakat. Terutama Pinang, buah sirih dan kapur. Sehingga jika di Papua responden dapat melakukan kebiasaan menyirih ini bisah lebih dari 5 kali dalam sehari. Kebiasaan ini dilakukan sesering mungkin dalam keseharian masyarakat Papua. ${ }^{8,9}$ Jika di biarkan kebiasaan ini terus menerus dapat menyebabkan lesi pada permukaan mukosa mulut. Bahkan dari beberapa penelitian yang menyebutkan kebiasaan ini dapat menyebabkan kanker pada rongga rongga mulut. ${ }^{7,10}$

Dari hasil penelitian diperoleh semua responden menggunakan Kapur, Pinang, daun/buah Sirih, sebagai komposisi bahan utama ketika melakukan kebiasaan menyirih dan tidak ada bahan tambahan lain seperti gambir dan tembakau. Sehingga tidak dapat melakukan uji korelasi menggunakan chi-square test untuk menganalisis hubungan antara komposisi menyirih dengan status kesehatan periodontal. Dalam penelitianpenelitian sebelumnya mengatakan bahwa komposisi menyirih dapat mempengaruhi status kesehatan periodontal, disebabkan terdapat kalsium pada komposisi yang digunakan pada saat menyirih. ${ }^{7,11}$

\section{SIMPULAN}

Berdasarakan pembahasan penelitian yang dilakukan dapat diambil kesimpulan bahwa status kesehatan periodontal pada mahasiswa etnis Papua di Manado adalah buruk sebanyak 32 orang $(76,2 \%)$. Terdapat hubungan frekuensi menyirih dalam sehari dengan status kesehatan periodontal. Dan tidak ada hubungan antara lama menyirih dengan status kesehatan periodontal.

\section{SARAN}

Perlu dilakukan promosi kesehatan secara terus menerus untuk merubah perilaku masyarakat etnis Papua yang masih mempertahankan kebiasaan menyirih. Selain itu, perlu dilakukan penelitian lanjutan dengan menggunakan uji laboratorium komposisi menyirih, untuk mengetahui faktor mana yang paling dominan dari komposisi menyirih yang paling berpengaruh terhadap status kesehatan periodontal.

\section{DAFTAR PUSTAKA}

1. Putri $\mathrm{MH}$, Herijulianti E, Nurjannah $\mathrm{N}$. Ilmu pencegahan penyakit jaringan keras dan jaringan pendukung gigi. Jakarta:EGC.2010.

2. Damyanti R, Mulyono. Khasiat dan manfaat daun sirih obat mujarab dari masa ke masa. Jakarta. Agro Media pustaka;2005.

3. Hasibuan S, Permana G, Aliah S. Mukosa mulut yang dihubungkan dengan kebiasaan menyirih di kalangan penduduk Tanah Karo Sumatra Utara. Available from: URL: http://repository,usu.ac.id/handle/1234 56789/3957. Diuduh. 22 April 2013.

4. Siagian VK. Status kebersihan gigi dan mulut suku Papua pengunyah pinang di Manado. Dentofasial. Jurnal kedokteran gigi Vol.11 No 1 februarari 2012.Hal.1-6.

5. Wanaha MAL. Hasil wawancara kompas dengan dosen FISIP Uncen Jayapura. kompas edisi 24 september 2003. Diunduh dari : http://www.kompas.com/kompascetak/0309/24/iptek/578008.htm2003 (diakses 25 April 2013).

6. Thomas ANS. Tanaman obat radisional. Kanisius. Available from: URL:

http://books.google.co.uk/books?id. Diunduh 29 April 2013.

7. Sama R. Kebiasaan mengunyah sirih dan hubungan dengan indeks penyakit periodontal pada wanita di Kecamatan Lau Belang Kabupaten Karo. Available from: http://www.repository.usu.ac.id/handl 
e/123456789/8032. Diunduh 25 April 2013.

8. Samura JAP. Pengaruh budaya makan sirih terhadap status kesehatan jaringan periodontal pada masyarakat suku Karo di Desa Biru-Biru Kabupaten Deli Serdang tahun 2009. Available from: URL: repository.usu.ac.id/handle/12345678 9/6914. Diunduh 25 April 2013.

9. Perry, Dorothy A. Beemsterboer, Phyllis L. periodontology for the dental hygienist. $3^{\text {rd }}$ ed: Saunders Elsevier,2007.

10. Ridzuan NZB. Kanker rongga mulut disebabkan oleh kebiasaan menyirih (laporan Kasus). [Serial online]2009[cites 2013 oktober 16]; available from: URL:

http://repository.usu.ac.id/handle/1234 56789/7897

11. Efrata F. Analisa kandungan nikotin pada tembakau (Nicotiana tabacum) yang digunakan sebagai tembakau kunyah dan karakteristik masyarakat penggunanya di Desa Rumah Gerat Kecamatan Biru-Biru Kabupaten Deli Serdang tahun 2010. [serial online]2011[cites2013 Mey14] Available from: URL: http://repository,usu.ac.id/handle/1234 56789/22539. 